\title{
Technical report: Analysis of citrated blood with thromboelastography: comparison with fresh blood samples
}

\author{
[Compte-rendu technique: Analyse d'échantillon sanguin citraté par \\ thromboélastographie : une comparaison avec des échantillons frais]
}

Marcin Wasowicz MD, ${ }^{*}$ Coimbatore Srinivas MD, ${ }^{*}$ Massimiliano Meineri MD, ${ }^{*}$ Brie Banks BSc, * Stuart A. McCluskey MD, ${ }^{*}$ Keyvan Karkouti MD*$\dagger$

Purpose: Thromboelastography (TEG) evaluates the viscoelastic properties of whole blood to assess clot formation and hemostasis. When blood cannot be analyzed immediately, it is stored in citrated tubes to be analyzed after recalcification. In this study, we evaluated the results of TEG analysis performed on citrated blood and compared these results to values obtained from activated (kaolin and tissue factor) and non activated, fresh blood samples, obtained at various time intervals (one, two, and three hours).

Methods: Four blood samples were collected from each of ten healthy volunteers. The following TEG analyses were performed on each sample: reaction time $(r), k$ time $(k)$, alpha angle $(\alpha)$, and maximum amplitude (MA). Studies were done using fresh, non citrated blood, obtained within five minutes of collection, and using citrated blood, one, two, and three hours after collection. Samples were analyzed, with and without activation, using kaolin and tissue factor.

Results: Tissue factor activated and non activated, citrated samples had shorter $r$ and $k$ times $(P=0.03, P=0.008, P<$ $0.000 \mathrm{I}$, and $P<0.000 \mathrm{I}$, respectively) and higher alpha angle and $M A$ values $(P<0.000 \mathrm{I}, P<0.000 \mathrm{I}, P=0.79$, and $P=$ 0.03 , respectively) compared to fresh, non citrated samples. These findings were consistent with a hypercoagulable state. Conversely, citrated samples, activated with kaolin, yielded results similar to those obtained from fresh, non citrated samples. The TEG measurements were similar among citrated samples stored from one to three hours.
Conclusions: Our results demonstrate that TEG measures, performed on citrated blood samples, yield results that are consistent with a hyperocoagulable state. Using kaolin to activate citrated samples, on the other hand, yields results similar to those obtained from non citrated, fresh blood samples.

CAN J ANESTH $2008 / 55: 5 /$ pp 284-289

Objectif: La thromboélastographie (TEG) évalue les propriétés viscoélastiques du sang complet afin d'évaluer la formation de caillots et l'hémostase. Lorsque le sang ne peut pas être immédiatement analysé, il est stocké dans des tubes citratés afin d'être analysé après recalcification. Dans cette étude, nous avons évalué les résultats d'analyse TEG obtenus sur des échantillons de sang citraté et avons comparé ces résultats aux valeurs obtenues à partir d'échantillons de sang frais, activé (kaolin et facteur tissulaire) et non activé, lesquels avaient été obtenus à différents intervalles de temps (une, deux et trois heures).

Méthode : Dix volontaires sains ont chacun donné quatre échantillons de sang. Les analyses TEG suivantes ont été effectuées sur chaque échantillon: temps de réaction $(r)$, temps $k(k)$, angle alpha $(\alpha)$ et amplitude maximale (MA). Des études ont été faites avec du sang frais et non citraté dans les cinq minutes suivant son obtention, ainsi qu'avec du sang citraté une, deux et trois heures après la collecte. Les échantillons ont été analysés avec ou sans activation à l'aide de kaolin et de facteur tissulaire.

From the Department of Anesthesia, ${ }^{*}$ Toronto General Hospital, University Health Network; and the Department of Health Policy, $\dagger$ Management and Evaluation, University of Toronto, Toronto, Ontario, Canada.

Address correspondence to: Dr. Marcin Wasowicz, Department of Anesthesia, Toronto General Hospital, 200 Elizabeth St., EN3-424, Toronto, Ontario M5G 2C4, Canada. Phone: 416-340-4800, ext. 3350; Fax: 416-340-3698; E-mail: marcin.wasowicz@uhn.on.ca Funding: Haemoscope Inc. provided the Thromboelastographs® used in this study.

The study was funded, in part, from the Department of Anesthesia, Toronto General Hospital, University Health Network, University of Toronto.

Competing interests: K. Karkouti has received operating grant support from Canadian Institutes of Health Research. He receives partial research salary support from the Canadian Anesthesiologists' Society/Bristol Myers Squibb Career Scientist Award in Anesthesia. No other author has any conflicts of interest related to this study.

Accepted for publication December 19, 2007.

Revision accepted January 29, 2008.

Final revision accepted February 21, 2008. 
Résultats : Les échantillons citratés activés et non activés avec le facteur tissulaire ont présenté des temps $r$ et $k(P=0,03, P=$ $0,008, P<0,0001$, et $P<0,0001$, respectivement) plus courts ainsi qu'un angle alpha et des valeurs MA plus élevés $(P<0,0001$, $P<0,0001, P=0,79$, et $P=0,03$, respectivement) que les échantillons frais et non citratés. Ces résultats coïncident avec un état hypercoagulable. En revanche, les échantillons citratés activés avec kaolin ont donné des résultats similaires à ceux obtenus à partir d'échantillons frais non citratés. Les mesures TEG étaient semblables pour les échantillons citratés stockés de une à trois heures.

Conclusion: Nos résultats démontrent que les mesures TEG, effectuées sur des échantillons de sang citratés, donnent des résultats qui coïncident avec un état hypercoagulable. L'utilisation de kaolin pour activer des échantillons citratés, en revanche, donne des résultats similaires à ceux obtenus d'échantillons de sang frais non citraté.

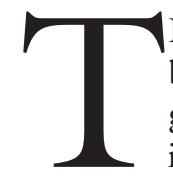

HROMBOELASTOGRAPHY (TEG) has been used to monitor coagulation ${ }^{1}$ and to guide management of blood transfusion in liver transplantation, ${ }^{2}$ cardiac surgery, ${ }^{3}$ trauma, ${ }^{4}$ and postpartum hemorrhage. ${ }^{5,6}$ The theoretical advantage of TEG, over the standard monitors of coagulation (including: prothrombin time; activated, partial thromboplastin time; fibrinogen level; and platelet count), is that TEG uses whole blood to provide information on the entire clotting process (including: initiation and speed of clot formation; clot strength; and fibrinolysis).

Thromboelastography analysis can be performed on non citrated or citrated blood. The advantage of non citrated blood is the avoidance of contact activation related to sample storage. The disadvantage is the necessity to perform the analysis within five minutes of sampling, a task that is not always feasible. The latter issue is resolved when blood is stored in citrated tubes, which allows for delayed TEG analysis. There is some concern, however, that TEG results obtained from citrated blood samples may yield results different from those obtained from fresh, non citrated blood samples. ${ }^{7-10}$ Another concern is that the storage time of citrated blood samples may influence TEG measures. ${ }^{7-9,11}$ Consequently, to compare the results of TEG analysis, performed on non citrated blood, analyzed within five minutes of collection, with the values of citrated blood, stored, with and without use of activators, for one to three hours, we carried out this observational study on healthy volunteers.

\section{Methods}

After we obtained institutional Research Ethics Board approval for this study, we recruited ten, healthy volunteers from amongst coworkers employed at our Institution (Department of Anesthesia). All participants gave written, informed consent for their participation. Inclusion criteria called for participants of either gender, who were in good health and not on any medications that could potentially affect coagulation. Exclusion criteria involved potential participants with the presence of any systemic disease, or who used medications (including herbal medications and overthe-counter drugs) that might affect coagulation.

Thromboelastography measurements (Figure 1) were performed using two TEG 5000 analyzers ${ }^{\circledR}$ (Haemoscope, Niles, IL, USA). The applied methodology was as recommended by the manufacturer. All blood samples were taken from a $20 \mathrm{G}$ catheter (Angiocath, Becton Dickinson, Sandy, UT, USA) inserted into the antecubital vein under minimal venous stasis. Thirty seconds after releasing the tourniquet, $5 \mathrm{~mL}$ of blood was collected and discarded. An additional $15 \mathrm{~mL}$ of blood was collected into a $20-\mathrm{mL}$ syringe with gentle suction. Parts of the blood sample were then transferred into three $1.8 \mathrm{~mL}, 3.2 \%$ sodium citrate, blue-top vacutainers (Becton Dickinson). The tubes were stored undisturbed, at room temperature, for up to three hours. The remaining blood was used for 'fresh sample' TEG analysis directly from the syringe.

All samples were analyzed, as per standard operating instructions provided by Haemoscope. The following three tests were performed on fresh, non -activated samples. 1) For the non activated analysis, $360 \mu \mathrm{L}$ of blood was transferred into the sampling cup and processed. 2) For kaolin activated analysis, $1 \mathrm{~mL}$ of blood was first transferred into a standard kaolin cup and then mixed by three gentle inversions. The blood $(360 \mu \mathrm{L})$ was next transferred to the sampling cup and processed. 3) For tissue factor (TF) activated analysis, $10 \mu \mathrm{L}$ of diluted TF (Dade Behring, Marburg, Germany) was first added to the sampling cup. TF dilution was as follows: $10 \mathrm{~mL}$ of distillated water was added to the TF powder; then $100 \mu \mathrm{L}$ of the solution was diluted once more with $9.9 \mathrm{~mL}$ of distillated water. Blood $(350 \mu \mathrm{L})$ was added to the cup and processed.

Citrated samples were similarly analyzed after one, two, and three hours of storage, with the following modifications. For recalcification, $20 \mu \mathrm{L}$ of calcium chloride was added to the TEG sampling cups. For the non activated and kaolin activated analysis, 340 $\mu \mathrm{L}$ of blood was added to the sampling cup and gently 


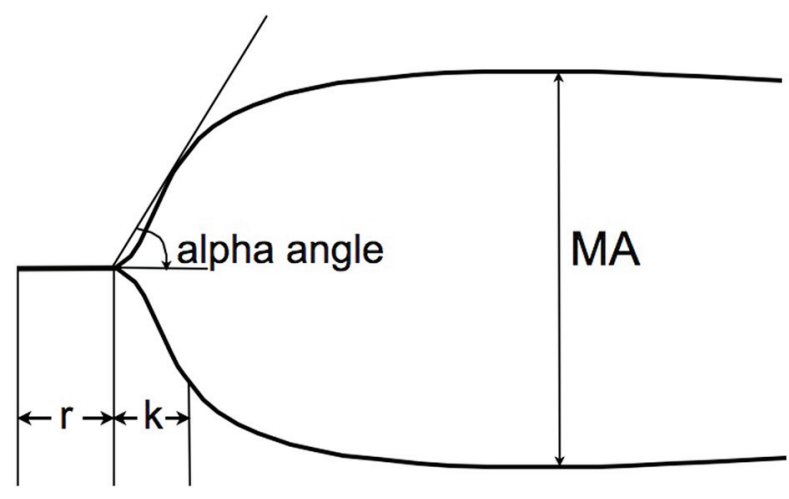

FIGURE 1 Normal thromboelastogram (TEG) showing the derivation of $\mathrm{r}$ time, $\mathrm{k}$ time, alpha angle, and maximum amplitude (MA).

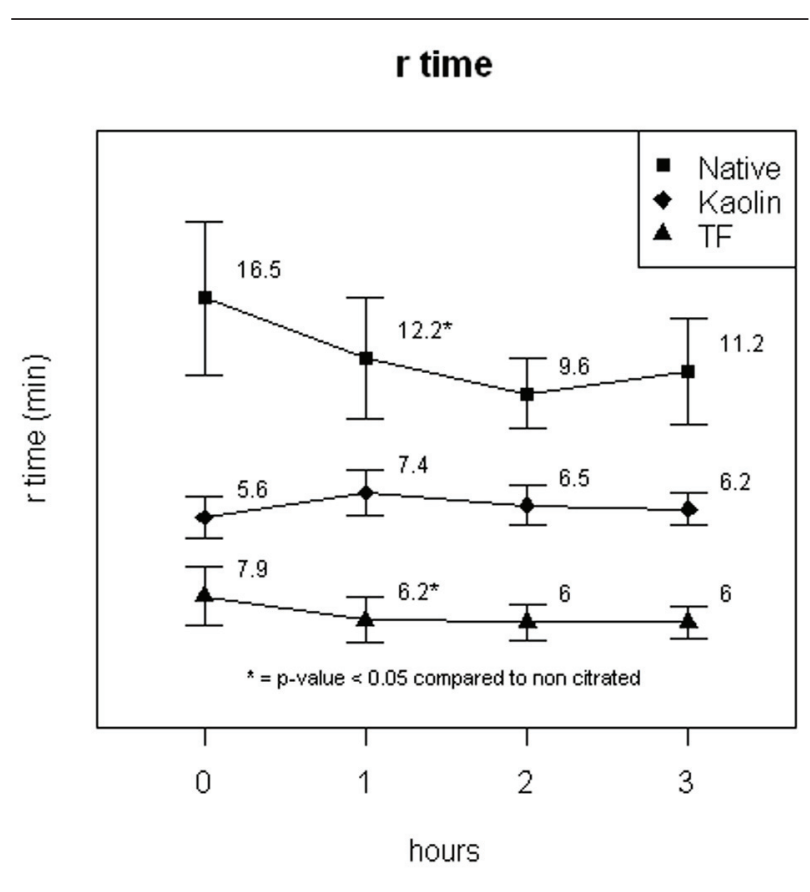

mixed with calcium chloride using a micropipette. For the TF activated analysis, $330 \mu \mathrm{L}$ of citrated blood was added to the sampling cup and gently mixed. At each time point, a separate citrated sample was used for analysis.

\section{Statistical analysis}

SAS $^{\mathrm{TM}}$ version 8.2 (SAS Institute, Inc., Cary, NC, USA) was used for statistical analyses. For each activator type, TEG measurement differences were analyzed by repeated measures ANOVA using a general mixed model approach (with PROC MIXED). Time was considered as nominal variable, with time $=0$ corresponding to fresh blood measurements. A series of Bonferroni adjusted (to control for false positive findings) pair wise comparisons were performed to study the effect of time on test scores.

\section{Results}

We screened ten potential participants and all of them met the inclusion criteria, agreed to participate in the study, and gave informed consent. Eight male and two female subjects were enrolled. Their ages ranged from 26 to $40 \mathrm{yr}$ (median $34 \mathrm{yr}$ ).

Thromboelastography values obtained from fresh, non citrated blood (zero hours) and from citrated blood at one, two, and three hours are graphically presented in Figures $2-5$ [showing the $r, k, \alpha$, and maximum amplitude (MA) values, respectively].

Citrated, non activated samples tested at one, two, and three hours of storage had a shorter $\mathrm{r}$ time and $\mathrm{k}$ time, as well as a greater alpha angle and MA, com-
FIGURE 2 Thromboelastogram results of $\mathrm{r}$ time (time $=$ 0 ) and citrated blood at one, two, and three hours after storage. Blood samples were analyzed without activation ( $\boldsymbol{\square}$, native), with tissue factor $(\mathrm{TF})$ activation $(\boldsymbol{\bullet}, \mathrm{TF})$, and with kaolin activation $(\bullet$, kaolin). Values are expressed as mean \pm standard deviation. Asterisks indicate results which were statistically significant $(P=0.008, P=0.03$, and $P=$ 0.35 for native, TF, and kaolin measurements, respectively).

pared with fresh, non citrated samples $(P=0.008, P$ $<0.0001, P<0.0001$, and $P=0.03$, respectively). Results of TEG analysis of citrated, non activated samples tested at one, two, and three hours of storage were similar.

Citrated, TF activated samples, tested at one, two, and three hours of storage, compared with fresh TF activated samples, had a shorter $\mathrm{r}$ time and $\mathrm{k}$ time, as well as a higher alpha angle, compared with fresh, non citrated samples $(P=0.03, P<0.0001$, and $P<$ 0.0001 , respectively). The MA values of citrated and fresh, non citrated, TF activated samples were not significantly different $(P=0.79)$. Results of TEG analysis of citrated, TF activated samples, tested at one, two, and three hours of storage, were similar.

Citrated, kaolin activated samples, tested at one, two, and three hours of storage, yielded similar $r$ time and alpha angle compared with fresh, non citrated samples $(P=0.35$, and $P=0.08$, respectively). On the other hand, citrated, kaolin activated samples had longer $\mathrm{k}$ time and lower MA than non citrated, fresh 


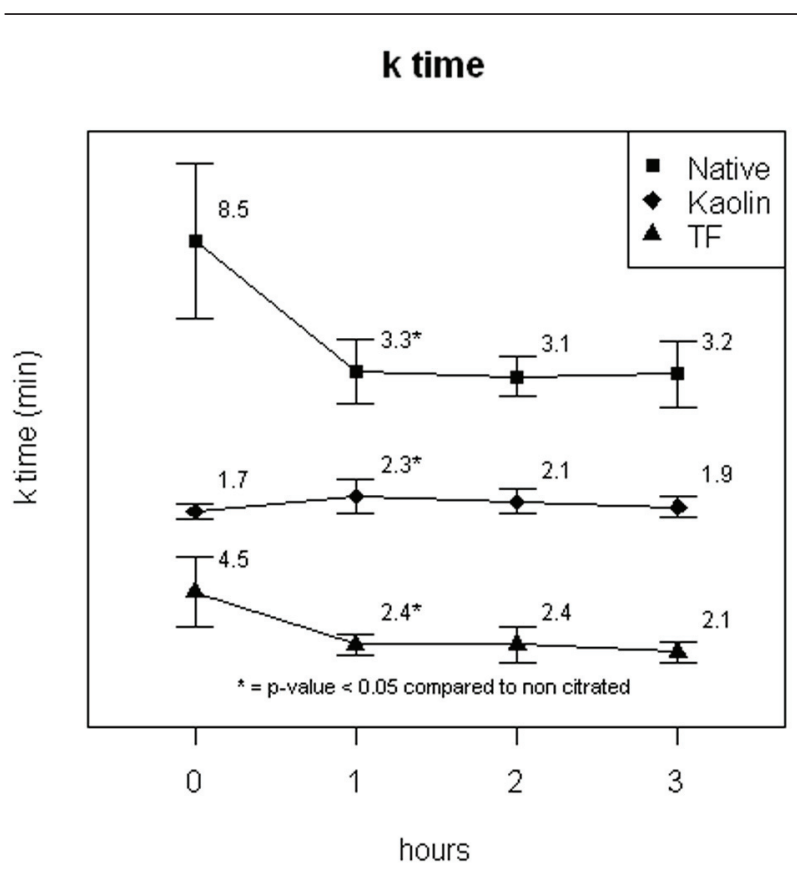

FIGURE 3 Thromboelastogram results of $\mathrm{k}$ time (time $=$ 0 ) and citrated blood at one, two, and three hours after storage. Blood samples were analyzed without activation $(\boldsymbol{\square}$, native), with tissue factor $(\mathrm{TF})$ activation $(\boldsymbol{\bullet}, \mathrm{TF})$, and with kaolin activation $(\bullet$, kaolin). Values are expressed as mean \pm - standard deviation. Asterisks indicate results, which were statistically significant $(P<0.0001, P<0.0001$, and $P=0.03$ for native, TF, and kaolin measurements, respectively).

samples $(P=0.03$ and $P<0.001)$. Results of TEG analysis of citrated, kaolin activated samples, tested at one, two, and three hours of storage, were not significantly different.

\section{Discussion}

In this study, we compared the results of TEG analyses, using fresh, non citrated blood samples, with the results of citrated samples stored for one, two, and three hours. We found that the duration of storage of citrated blood had no discernable effect on non activated or activated (with TF or kaolin) TEG analyses. On the other hand, we observed that the results of TEG analyses were different when comparing fresh, non citrated and citrated blood samples. Except for kaolin activated measures, citrated blood samples showed changes that would be consistent with a hypercoagulable state. These changes were most striking in the non activated samples, but they were also present in TF activated samples.

\section{$\alpha$ angle}

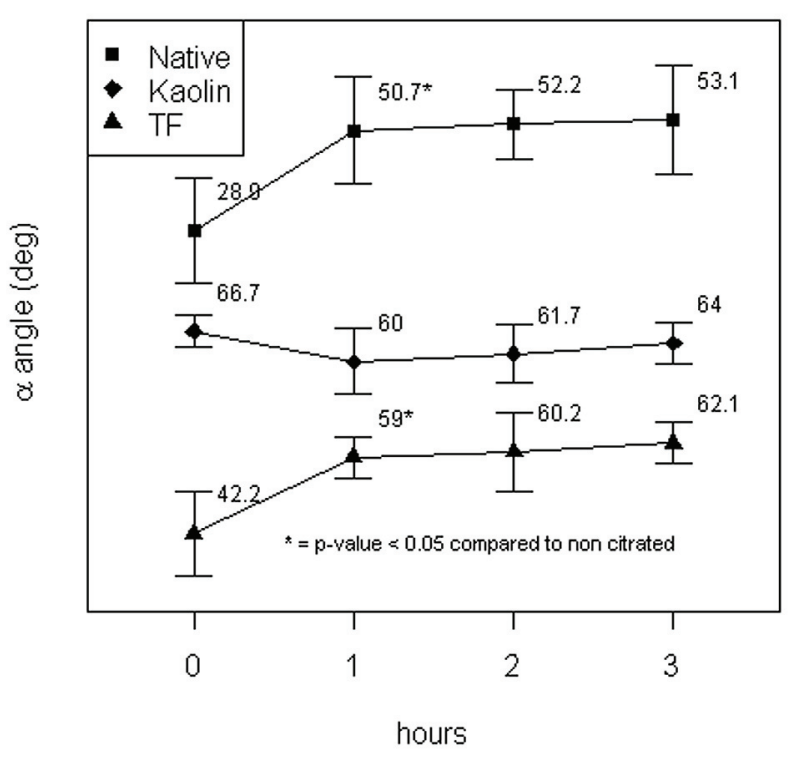

FIGURE 4 Thromboelastogram results of alpha angle (time $=0$ ) and citrated blood at one, two, and three hours after storage. Blood samples were analyzed without activation ( $\boldsymbol{\square}$, native), with tissue factor $(\mathrm{TF})$ activation $(\boldsymbol{\bullet}, \mathrm{TF})$, and with kaolin activation ( $\bullet$, kaolin). Values are expressed as mean \pm standard deviation. Asterisks indicate results which were statistically significant $(P<0.0001, P<0.0001$, and $P=0.08$ for native, tissue factor (TF), and kaolin measurements, respectively).

Several previous studies have evaluated the stability of citrated blood samples for TEG analysis and have compared the use of citrated and non citrated blood samples for TEG. These studies, however, examined different study populations and applied different methodologies, yielding somewhat inconsistent results (Table). Collectively, these studies show that citrated samples are unstable for the first $30 \mathrm{~min}$ of storage, but are stable, thereafter, for up to eight hours. ${ }^{9}$ In most studies, a hypercoagulable trend has been observed with stored citrated samples, compared with non citrated, fresh samples. Among these, only one study investigated severely ill patients. ${ }^{10}$ In this study, no differences were observed when comparing fresh and citrate-stored blood samples.

Our study adds new information to the existing data, by showing that the hypercoagulable trend, with citrated samples, is present when no activator is used, or when TF, but not kaolin, is added to activate the sample. 


\section{Maximum amplitude (ma)}

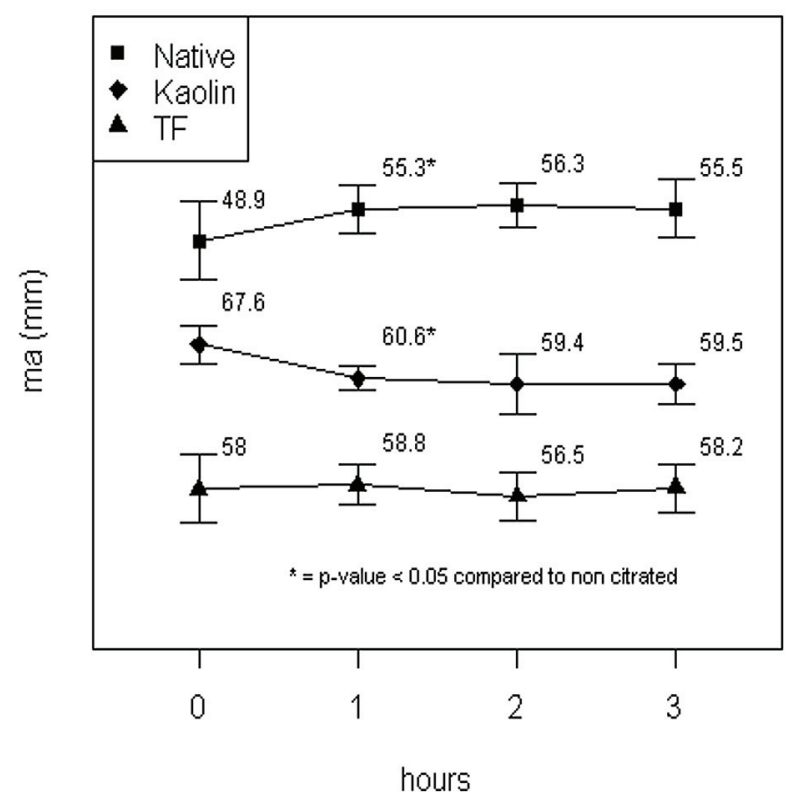

FIGURE 5 Thromboelastogram results of maximum amplitude (time $=0$ ) and citrated blood at one, two, and three hours after storage. Blood samples were analyzed without activation ( $\boldsymbol{\square}$, native), with tissue factor (TF) activation $(\bullet, T F)$, and with kaolin activation $(\bullet$, kaolin). Values are expressed as mean \pm standard deviation. Asterisks indicate results which were statistically significant $(P=0.03, P=$ 0.79 , and $P<0.001$ for native, TF, and kaolin measurements, respectively.
There are several possible explanations for the apparent "hypercoagulable state" of citrated samples. Camenzind et al. ${ }^{9}$ postulated that citrate may be responsible for incomplete inhibition of thrombin formation. Additionally, Bowbrick et al. ${ }^{8}$ were able to prolong stability of citrate-stored samples by cooling them to $4^{\circ} \mathrm{C}$, hence inhibiting platelet function. Another explanation is the possibility that transferring a blood sample from the syringe to the TEG cup may result in contact activation. ${ }^{11}$

The reason that a hypercoagulable tendency was not observed in kaolin activated samples is unclear. Nevertheless, these findings suggest that TEG measures on citrated blood samples should be performed with kaolin, rather than with TF activation.

Our study has several limitations. Firstly, the study cohort consisted of ten, healthy volunteers. Based on previous studies of TEG on volunteers, ${ }^{7,8,11}$ we anticipated that this sample size would provide a precise estimate of the distribution of TEG measures. The sample size, however, was too small to allow us to analyze gender effects on TEG measurements. Sorensen et al. ${ }^{12}$ have shown that gender may influence TEG measures. Secondly, because we recruited healthy volunteers, our findings may not be applicable to patients with congenital or acquired coagulation defects, where TEG measure distributions are likely to be more variable and abnormal. ${ }^{11}$ Finally, we did not perform TEG analyses with citrated samples during the first hour of storage and, consequently, we cannot comment on sample stability during this time. Previous studies have found that citrated samples produce unstable results during the first $30 \mathrm{~min}$ of storage..$^{9,11}$

TABLE Summary findings from previous studies

\begin{tabular}{|c|c|c|c|c|c|}
\hline Study & Sample & $n$ & Sample storage time & Activator & Main results \\
\hline Zambruni et al. ${ }^{7}$ & Volunteers & 10 & $30 \mathrm{~min}-4 \mathrm{hr}$ & No activators & $\begin{array}{l}\text { Stable conditions of storage between } 30 \mathrm{~min} \\
\text { and } 2 \mathrm{hr} \text {. No significant changes for } \mathrm{r} \text { time. } \\
\text { Significant changes towards } \\
\text { hypercoagulability for remaining variables. }\end{array}$ \\
\hline Bowbrick et al. ${ }^{8}$ & Volunteers & 8 & $30 \mathrm{~min}-2 \mathrm{hr}$ & No activators & $\begin{array}{l}\text { No significant difference between fresh } \\
\text { sample and storage after } 30 \mathrm{~min} \text { at room } \\
\text { temperature or at } 4^{\circ} \mathrm{C} \text {, for } 150 \mathrm{~min} \text {. }\end{array}$ \\
\hline Camenzind $e t a l^{9}$ & Surgical patients & $\begin{array}{l}30 \\
\text { patients } \\
\text { studied }\end{array}$ & $1-72 \mathrm{hr}$ & Celite & $\begin{array}{l}\text { Stable conditions of storage between } 1-8 \mathrm{hr} \text {. } \\
\text { Apparent hypercoagulable state in citrate } v s \\
\text { non citrated sample. }\end{array}$ \\
\hline Mancuso et al. ${ }^{10}$ & $\begin{array}{l}\text { Patients with } \\
\text { liver failure }\end{array}$ & 32 & $1-2 \mathrm{hr}$ & No activators & $\begin{array}{l}\text { No difference between fresh and citrate- } \\
\text { stored samples. }\end{array}$ \\
\hline Vig et al. ${ }^{11}$ & Volunteers & 10 & $30-180 \mathrm{~min}$ & $\begin{array}{l}\text { Celite and } \\
\text { tissue factor }\end{array}$ & $\begin{array}{l}\text { Stable conditions of storage between } \\
30-90 \text { min for non-activated samples. Stable } \\
\text { conditions of storage between } 10-90 \mathrm{~min} \\
\text { for celite activated samples. }\end{array}$ \\
\hline
\end{tabular}


In conclusion, our results demonstrate that TEG measures performed on citrated blood samples yield results that are consistent with a hypercoagulable state. Using kaolin to activate citrated samples, on the other hand, generates results which are similar to those obtained from non citrated, fresh samples. Future studies are warranted to determine whether these findings can be replicated in healthy subjects and, more importantly, in patients with congenital or acquired coagulopathies.

\section{References}

1 Mallett SV, Cox DJ. Thrombelastography. Br J Anaesth 1992; 69: 307-13.

2 Kang YG, Martin DJ, Marquez J, et al. Intraoperative changes in blood coagulation and thrombelastographic monitoring in liver transplantation. Anesth Analg 1985; 64: 888-96.

3 Spiess BD, Gillies BS, Chandler W, Verrier E. Changes in transfusion therapy and reexploration rate after institution of a blood management program in cardiac surgical patients. J Cardiothorac Vasc Anesth 1995; 9: 168-73.

4 Kaufmann CR, Dwyer KM, Crews JD, Dols SJ, Trask $A L$. Usefulness of thrombelastography in assessment of trauma patient coagulation. J Trauma 1997; 42: 716-22.

5 Sharma SK, Vera RL, Stegall WC, Whitten CW. Management of a postpartum coagulopathy using thrombelastography. J Clin Anesth 1997; 9: 243-7.

6 Sharma SK, Philip J, Wiley J. Thromboelastographic changes in healthy parturients and postpartum women. Anesth Analg 1997; 85: 94-8.

7 Zambruni A, Thalheimer U, Leandro G, Perry D, Burroughs $A K$. Thromboelastography with citrated blood: comparability with native blood, stability of citrate storage and effect of repeated sampling. Blood Coagul Fibrinolysis 2004; 15: 103-7.

8 Bowbrick VA, Mikbailidis DP, Stansby G. The use of citrated whole blood in thromboelastography. Anesth Analg 2000; 90: 1086-8.

9 Camenzind V, Bombelli T, Seifert B, et al. Citrate storage affects thrombelastograph analysis. Anesthesiology 2000; 92: 1242-9.

10 Mancuso A, Fung K, Cox D, Mela M, Patch D, Burroughs $A K$. Assessment of blood coagulation in severe liver disease using thromboelastography: use of citrate storage versus native blood. Blood Coagul Fibrinolysis 2003; 14: 211-6.

11 Vig S, Chitolie A, Bevan DH, Halliday A, Dormandy $G$. Thromboelastography: a reliable test? Blood Coagul Fibrinolysis 2001; 12: 555-61.

12 Sorensen B, Jobansen P, Christiansen K, Woelke M,
Ingerslev J. Whole blood coagulation thrombelastographic profiles employing minimal tissue factor activation. J Thromb Haemost 2003; 1: 551-8. 